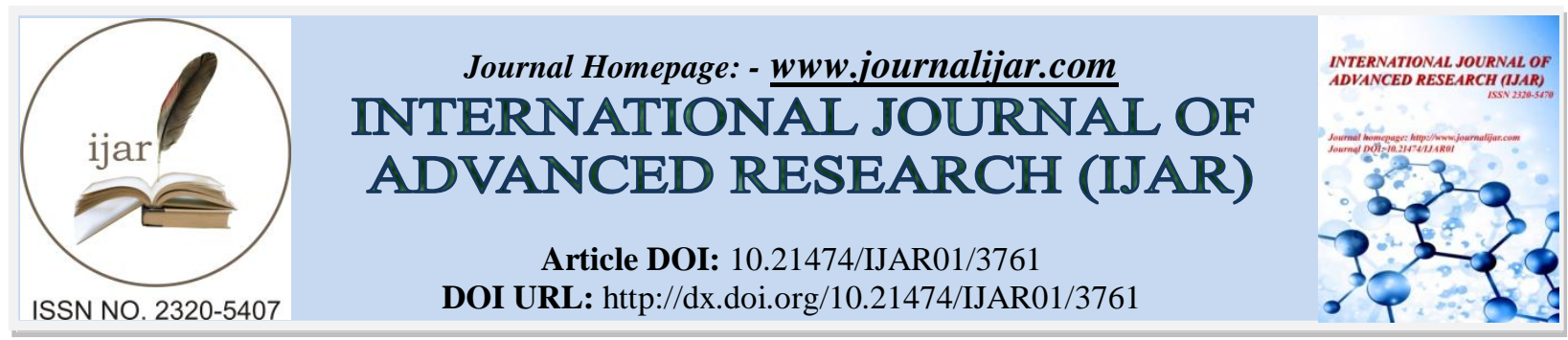

RESEARCH ARTICLE

\title{
ESTABLISHMENT OF PLAQUE ASSAY METHOD FOR TITRATING YELLOW FEVER VACCINE
}

\section{${ }^{*}$ Ankita Semwal ${ }^{1}$, Dr. Arun Bhardwaj ${ }^{2}$, Sushil Kumar Sahu ${ }^{2}$, Pallavi Kapoor ${ }^{2}$, Kanika Sharma ${ }^{3}$, Shweta Tandon $^{1}$ and Swati Chaudhary ${ }^{1}$.}

1. Central Research Institute, Kasauli.

2. Central Drugs Laboratory, Kasauli.

3. Bhojia Institute, Baddi.

\section{Manuscript Info}

Manuscript History

Received: 16 January 2017

Final Accepted: 16 February 2017

Published: March 2017

Key words:-

Vero cells, plaque assay, methyl

cellulose, Plaque Forming Unit (PFU),

Yellow fever 17D vaccine, potency test.

\begin{abstract}
The present study was undertaken with a view to look for the use of Vero cell line for plaque assay of Yellow fever vaccine, over Mouse $\mathrm{LD}_{50}$ method, for vaccine potency test. To establish the plaque assay the growth conditions for Vero cell line were standardized. Different parameters like cell count, dilution, inoculum size, adsorption time for virus, concentration for Methyl Cellulose (MC) in the overlay media and incubation period were standardized. And titration of Yellow fever vaccine was performed by Plaque Forming Unit (PFU) method. A cell concentration of $3-4 \times 10^{5}$ cells per $\mathrm{ml}$, in tissue culture plate gave a complete monolayer after overnight incubation. Virus dilution of $10^{-2}$ was optimum for desired pfu/ $0.5 \mathrm{ml}$. An inoculum size of $0.2 \mathrm{ml}$ per well was found suitable. Maximum plaques were obtained after an adsorption time of 4 hours, at $36 \pm 1{ }^{\circ} \mathrm{C}$, by 7 days of incubation. Different concentrations of methyl cellulose, overlay media were used. 1\% methyl cellulose in Minimum Essential Media (MEM) with 2\% FBS gave good results. The different samples of Yellow fever 17D vaccines were titrated by Plaque Assay method along with the IRS and titre results were compared with the titre values of manufacturer's potency assay. The vaccine pass the limit of minimum requirement of potency i.e., $4.24 \log _{10} \mathrm{PFU} / 0.5 \mathrm{ml}$ dose, equivalent to titre 1000 MouseLD $D_{50}$.
\end{abstract}

Copy Right, IJAR, 2017,. All rights reserved.

\section{Introduction:-}

Yellow fever was recognized as a clinical entity as early as in the seventeenth century and was familiar to pirates as the 'YELLOW JACK'. It is a native of Africa and was transported along the trade routes to Europe, America. The disease has been largely confined to certain areas of Africa and South and Central America. Yellow fever is a noncontagious acute infectious disease caused by the Yellow fever virus ${ }^{[1]}{ }^{[2]}$. Yellow Fever is member of family Flaviviridae, genus Flavivirus, and the virus after which the family and genus were named (flavus, Latin- Yellow). The virus has a small positive-sense, single stranded (ss) RNA genome. It is a spherical enveloped virus, bearing surface projections. Nucleocapsid has an icosahedral symmetry, 40-50 $\mathrm{nm}$ in diameter. 
It is a serious health problem with clinical symptoms that may vary from mild to severe disease characterized by sudden onset of fever and jaundice. The most serious forms also include hepatorenal syndrome, bleeding, shock and eventually evolve to death ${ }^{[3]}$. It is both Viscerotropic, causing liver disease and Neurotropic causing encephalitis ${ }^{[4]}$. Among various preventive measures such as vector control, improved hygiene and sanitation and immunization; immunization currently represents the least expensive and most effective means to prevent infection and to avoid subsequent disease ${ }^{[5]}\left[{ }^{[6]}\right.$. Yellow fever is a vaccine preventable disease and can be controlled by an effective vaccination program ${ }^{[7]}$.

Yellow fever was one of the most feared lethal diseases before the development of an effective vaccine ${ }^{[3]}$. The live attenuated vaccine of Yellow fever was developed in 1936 by Thieler \& Smith by attenuating Yellow fever virus Asibi strain through serial passages in tissue culture and animals, originating the 17D attenuated vaccines. Another French neurotropic vaccine was developed by Sellard and Laigret in 1932; it was popular as Dakar vaccine. The serious drawbacks of this vaccine were high incidences of encephalitic reactions in children. Due to which it was stopped being recommended for children under 14 years in 1961 and manufacturing of this vaccine strain was discontinued in $1980^{[8]}$.

Nowadays, there are two licensed vaccines available in international market, the first vaccine uses the 17D-214 strain and the second uses the 17DD strain (in Brazil) ${ }^{[9]}$.Yellow fever 17D vaccine has an outstanding feature that the vaccine provide protection against other Flaviviruses.

Vaccines are essential tool in the prevention of disease, as they protect the vaccinated individual from developing a potentially serious disease and helps in the reduction of spreading of infectious diseases. Thus the manufacturers are primarily responsible for the safety and efficacy of the vaccines. However, it is country's National Control Authority (NCA) that is responsible for establishing procedures for assuring that vaccines intended for use in that country are of adequate safety and efficacy. The activities required in this concept are incorporated under the responsibility of Quality Control (QC). The NCA grants approval for marketing vaccines and certify manufacturer by monitoring production, testing procedures and processes, performing QC testing of vaccines through National Control Laboratory (NCL) ${ }^{[10]}$.

QC tests for a vaccine are; sterility, identity, stability, toxicity, potency test etc. Potency is one of the most important parameters for the QC of vaccines. WHO requirements for potency testing of $17 \mathrm{D}$ vaccine are that the titre of the vaccine shall be not less than 1,000 mouse $\mathrm{LD}_{50} /$ dose $(0.5 \mathrm{ml})$ or its equivalent $\mathrm{PFU}{ }^{[11]}{ }^{[12]}$.Potency of Yellow fever is tested by two methods; $\mathrm{LD}_{50}, \mathrm{PFU}^{[11][12][13]}$

Mouse LD50 is a sensitive method but involves use of animals, with a long observation period i.e., 21 days and involves large number of animals ( 8 for each dilution). On the other hand plaque technique is quite sensitive, accurate, less time consuming method for titration. The PFU method gives result in 7 days, and has no use of animals. Many problems of taking care of mice, their food, and breeding etc., and problems faced due to premature death, variation in animal immune status, sensitivity to particular immunological products and variability in results can be avoided. Keeping in view the guidelines of RRR (Replacement, Refinement and Reduction of animals) for use of laboratory animals, an attempt has been made to perform the potency assay in vitro, i.e., PFU method. PFU method is equally sensitive method as mouse $\mathrm{LD}_{50}$ (in vivo method) ${ }^{[13]}$.

\section{Material and Method:-}

Vaccine:- The samples of the Live-attenuated, 17-D (204) Yellow fever vaccine, with diluent for suspension. Cell lines:- Vero Cell line was revived at passage level- 126 at CDL, Kasauli.

Reference Standard:- Yellow fever International Reference Standard (IRS); 99/616 IRS

\section{Media, Reagents And Solutions:-}

Buffers and solutions:-

- $\quad$ Sterile water for injection (W.F.I.).

- Distilled water: - Solutions used in all procedures were dissolved in distilled water.

- Washing Buffer: Phosphate buffer saline (pH7.4):- Sodium chloride (NaCl)-0.8gm, Potassium chloride (KCl)$0.020 \mathrm{gm}$, Sodium Hydrogen Phosphate $\left(\mathrm{Na}_{2} \mathrm{HPO}_{4}\right)-0.115 \mathrm{gm}$, Potassium Dihydrogen Phosphate $\left(\mathrm{KH}_{2} \mathrm{PO}_{4}\right)$ $0.020 \mathrm{gm}$. 
The above contents were mixed and solution was sterilized by autoclaving at $121^{\circ} \mathrm{C}, 15 \mathrm{lbs}$, for $20 \mathrm{~min}$. and stored at $2-8^{\circ} \mathrm{C}$.

- $\quad 0.25 \%$ Trypsin-EDTA (1X) (Dissociation Reagent);

\section{Staining and fixing reagents:-}

- $\quad$ Trypan Blue (0.4\% solutions):- The solution was used for cell counting.

- $\quad 0.5 \%$ Crystal Violet Solution:- Crystal Violet-2.5gm, Absolute ethanol-100ml, Formaldehyde (37-41\%) $135 \mathrm{ml}$, Distilled water-265ml. The above contents were mixed and filtered through filter paper. Solution is stored at room temperature. It was used for staining the plaques.

- Cell fixative, Formal saline (10\%):- Normal Saline (NaCl), NaCl-0.85gm, Distilled water-100ml.

- The above contents were mixed and solution was sterilized by autoclaving at $121^{\circ} \mathrm{C}, 15 \mathrm{lbs}$, for $20 \mathrm{~min}$.

- Formal Saline:- Formaldehyde (37-41\%)-10ml, Normal Saline-90ml. The solution is stored at room temperature. The solution was used as fixative i.e., for fixation of cells.

\section{Media:-}

- Foetal Bovine Serum (FBS), Sterile, gamma-irradiated, Mycoplasma tested; It was used at different concentrations in MEM. Stored at $2^{\circ} \mathrm{C}-8^{\circ} \mathrm{C}$.

- Minimum Essential Medium (MEM) 1X, MEM Alpha (1X) + GlutaMAX-I [-] Ribonucleosides, [-] Deoxyribonucleosides, Stored at $2^{\circ} \mathrm{C}$ to $8^{\circ} \mathrm{C}$.

- Penicillin-Streptomycin solution, Penicillin-[+] 5,000 units/ml,Streptomycin- $[+] 5,000 \mu \mathrm{g} / \mathrm{ml}$, Stored at $2^{\circ} \mathrm{C}$ to $8^{\circ} \mathrm{C}$.

- $\quad$ Growth medium- MEM=470ml, FBS-25ml, Pen/Strep (1\%)-5ml.

- Maintainance medium; MEM-483ml, FBS-12ml, Pen/Strep (1\%)-5ml.

- Overlay medium: Methyl Cellulose (1\% Stock solution):-

Solution A:- MEM-97ml, Methyl cellulose-1gm, Vigorous shaking of solution to mix methyl cellulose properly. Autoclave the solution at $121^{\circ} \mathrm{C}$, for $15 \mathrm{~min}$. Solution is cooled to room temperature.

Solution B:- FBS-2ml, Penicillin/Streptomycin-1ml.

Solution B was added to solution A; Stored at $2-8^{\circ} \mathrm{C}$.

\section{Materials And Equipments:-}

Tissue culture plates (Disposable, flat bottomed 6-Well-tissue-culture plates), Tissue culture bottles (Roux bottles) $\left(25 \mathrm{~cm}^{2}\right.$ and $75 \mathrm{~cm}^{2}$ sterile disposable cell culture bottles), Autopipettes, Disposable graduated pipette (5ml, $25 \mathrm{ml}$, $100 \mathrm{ml})$, Ependrroff, falcon tubes, Disposable syringe and needle $(5 \mathrm{ml})$. Glass vials, Measuring cylinders, Glass bottles, Beakers, flasks. Disposable gloves, masks, tissue paper, vaccine vial opener, glass vial stand, vortex mixer, haemocytometer, inverted microscope, bio-safety cabinet, autoclave, deep freezer and refrigerator, carbon dioxide incubator.

\section{Method:-}

Revival and Propagation of Vero cell line:-

Vero cell line was obtained from CDL, Kasauli at passage level-126 (P-126). The ampoules containing Vero cell line, were stored at $-196^{\circ} \mathrm{C}$ in cryopreservation system (in liquid Nitrogen), were removed and transferred immediately to water bath at $36^{\circ} \mathrm{C} \pm 1{ }^{\circ} \mathrm{C}$ till its content was completely thawed. Then outside of the ampoule was wiped with disinfectant to reduce contamination and the ampoules were opened in Bio-safety Cabinet. The cell suspension was transferred to culture bottles containing growth media, MEM with 5\%FBS. The bottles were incubated at $36^{\circ} \mathrm{C} \pm 1^{\circ} \mathrm{C}$ for $4 \mathrm{hrs}$. The media was decanted carefully to get rid of DMSO present and fresh growth medium was added for the production of cell monolayer and incubated at $36^{\circ} \mathrm{C} \pm 1{ }^{\circ} \mathrm{C}$ until the cell monolayer is complete.

\section{Maintenance of cell lines:-}

Cell lines were maintained at $32^{\circ} \mathrm{C}$ temperature with maintenance medium $\mathrm{MEM}+2 \% \mathrm{FBS}$.

\section{Tissue Culture:-}

\section{Trypsinization of Cells:-}

Once the monolayer was complete, the cells were harvested using the following procedure- 
- A freshly thawed trypsin was warmed to $36^{\circ} \mathrm{C} \pm 1{ }^{\circ} \mathrm{C}$ in incubator.

- The tissue culture bottle was observed under the inverted microscope, for following characteristics: - Confluent monolayer, healthy and viable cells, no or little granularity, no C.P.E., or other changes in the cell growth present.

- Using a sterile pipette, whole spent medium was aspirated from tissue culture bottle.

- The cell layer was rinsed gently with $5 \mathrm{ml}$ of $1 \mathrm{X}$ MEM.

- $0.25 \%$ trypsin solution was added to the cell monolayer, i.e., $1 \mathrm{ml}$ to $25 \mathrm{~cm}^{2}$ tissue culture bottles and $2-3 \mathrm{ml}$ to $75 \mathrm{~cm}^{2}$ tissue culture bottles.

- The tissue culture bottle was incubated in the incubator at $36^{\circ} \mathrm{C} \pm 1{ }^{\circ} \mathrm{C}$ until the cells starts detaching from the surface.

- Discard the trypsin before the cell monolayer detach entirely from the surface of the tissue culture bottle.

- The growth medium was added to cell culture bottle, $10 \mathrm{ml}$ to $25 \mathrm{~cm}^{2}$ culture bottles, $20 \mathrm{ml}$ to $75 \mathrm{~cm}^{2}$ culture bottles. The serum in the growth medium stops the action of trypsin still present.

- The media was aspirated gently to loosen the cells from the surface of the bottles and pooled the cell suspension from each bottle into new tissue culture bottle.

- Re-suspended the cells in growth medium to desired concentration, based on cell counting. Seed fresh culture bottles or 6-well tissue culture plates.

\section{Cell counting:-}

Cell counting was done for enumeration of viable cells per ml. accurate number of cells in a cell suspension was calculated by using haemocytometer (Neubauer chamber). Before cell counting the cells were dispersed thoroughly by pipetting in and out.

- Prepared 1:1 dilution of original cell suspension (obtained by trypsinisation) using $0.4 \%$ trypan blue as follows: $0.5 \mathrm{ml}$ of diluted cell suspension, $0.5 \mathrm{ml}$ of $0.4 \%$ trypan blue.

- The cell suspension was mixed well with pipette and immediately aspirated a sufficient volume to fill the haemocytometer.

- All viable (unstained) cells were counted in the 8 squares $(1.0 \mathrm{~mm})$ constituting the 4 corners of each of the two haemocytometer chamber, omitting cells lying on the upper line and left line of each square. The volume of each corner square $=0.1 \mathrm{~mm}^{3}(1.0 \times 1.0 \times 0.1)$.

- Calculated the mean count of the cells per $0.1 \mathrm{~mm}^{3}$.

- The number of cells in the suspension were calculated using the following formula: $\mathrm{N}=\mathbf{m} \times \mathrm{tb} \times \mathrm{V} \times 10^{4}$

\section{Where,}

$\mathbf{N}$-Total number of cells in the suspension

m- Mean of cell count in eight corners

tb- Trypan blue correction factor

V- Volume of original cell suspension in $\mathrm{ml}$

$\mathbf{1 0}^{4}$ - Conversion factor for haemocytometer

\section{PLAQUE ASSAY ${ }^{[14]}$}

\section{Preparation of the Vero Cell monolayer:-}

After counting cells, the cell concentration was adjusted to $3-4 \times 10^{5}$ Vero cells $/ \mathrm{ml}$ of cell suspension, in MEM with $5 \%$ FBS.

- $2 \mathrm{ml}$ of this cell suspension was added to each well of 6-well tissue culture plate.

- Tissue culture plates were incubated at $36^{\circ} \mathrm{C} \pm 1{ }^{\circ} \mathrm{C}$, at $5 \% \mathrm{CO} 2$, overnight for complete monolayer formation.

Reconstitution of Yellow fever vaccine:- Lyophilized vaccine $(0.5 \mathrm{ml}$ dose $)$ was diluted in the diluent provided with the vaccine. It was placed on ice bath till use.

\section{Preparation of vaccine dilution:-}

- The sterile glass vials were labelled as $10^{-1}, 10^{-2}, 10^{-3}, 10^{-4}$ and $10^{-5}$.

- The reconstituted vaccine was serially diluted in chilled dilution medium (MEM with 2\%FBS), in a range of $10^{-}$ ${ }^{1}$ to $10^{-5}$. 
- $\quad 0.9 \mathrm{ml}$ of chilled dilution medium was dispensed in all 5 -vials.

- The 10 -fold dilutions were prepared by adding $0.1 \mathrm{ml}$ of reconstituted vaccine into first vial $\left(10^{-1}\right)$, and mixed on vortex for 15-20 seconds and then transferring $0.1 \mathrm{ml}$ of $10^{-1}$ dilution to next vial making it $10^{-2}$ and vortex it, and similarly upto $10^{-5}$ dilution.

\begin{tabular}{|l|l|l|l|l|l|}
\hline \multicolumn{2}{|l|}{ Range of dilutions used in plaque assay of Yellow fever vaccine. } \\
\hline Dilution & $\mathbf{1 0}^{-\mathbf{1}}$ & $\mathbf{1 0}^{-\mathbf{2}}$ & $\mathbf{1 0}^{-3}$ & $\mathbf{1 0}^{-4}$ & $\mathbf{1 0}^{-\mathbf{5}}$ \\
\hline Diluent (in ml) & 0.9 & 0.9 & 0.9 & 0.9 & 0.9 \\
\hline Vaccine (in ml) & 0.1 & - & - & - & - \\
\hline
\end{tabular}

\section{Virus infection and Adsorption:-}

- The media was aspirated, from the wells of tissue culture plates with confluent monolayer of Vero cell line.

- $0.2 \mathrm{ml}$ of each viral dilution from $10^{-1}$ to $10^{-5}$ was added to different wells, minimum 2 wells for each dilution.

- Two wells will remain as the cell-control wells, and $0.2 \mathrm{ml}$ of medium (MEM+2\% FBS) was added to it.

- The plates were incubated for 4 hours, for adsorption of virus to the cell-monolayer. The plates were gently shaken after every 30 minutes, for uniform distribution of the inoculum.

\section{Addition of Overlay Medium:-}

- After $4 \mathrm{hrs}$ of adsorption, $3 \mathrm{ml}$ of methyl cellulose was added to all 6 wells of the plate, to stop the viral diffusion.

- The plates were incubated for 7 days, at $36^{\circ} \mathrm{C} \pm 1{ }^{\circ} \mathrm{C}$, at $5 \% \mathrm{CO}_{2}$ for the development of plaques.

Plaque Fixation and Staining:-

- $\quad$ On $7^{\text {th }}$ day, the overlay medium was aspirated from the wells, and the plates were washed 2-times with PBS $2 \mathrm{ml}$ per well.

- $\quad$ The cells were fixed with $2 \mathrm{ml}$ per well $10 \%$ formal saline solution for 30 minutes.

- After fixation aspirated the fixative and the plates were washed with PBS.

- The plates were stained with $0.5 \%$ crystal violet stain solution for 30 minutes at room temperature.

- The plates were washed with PBS 2-3 times and air dried.

- After proper drying of tissue culture plates, the plates were examined to count the number of plaques, comparing with the cell control.

Calculation of results (PFU/0.5ml dose):-

The number of Plaque Forming Units (PFU), were titred per $0.5 \mathrm{ml}$ dose.

Formula: $-\mathrm{PFU}=\mathbf{P} \times \mathrm{D} \times \mathbf{2 . 5}$

Where: - P - Average No. of plaques

D- Reciprocal of Dilution factor

2.5- Correction factor for $0.5 \mathrm{ml}$ dose

\section{Results:-}

\section{Cell count:-}

The cell count of $3-4 \times 10^{5}$ cells $/ \mathrm{ml}$ gave a complete monolayer when $2 \mathrm{ml}$ of this suspension was used per well of the 6-well tissue culture plate. (Table-1)

Table 1:- Standardization of the Cell Count.

\begin{tabular}{|c|c|c|}
\hline Cell count & Incubation time & Result \\
\hline $2 \times 10^{5}$ & Overnight Incubation & Incomplete Monolayer Formation \\
\hline $3 \times 10^{5}$ & Overnight Incubation & Complete Monolayer Formation \\
\hline $4 \times 10^{5}$ & Overnight Incubation & Complete Monolayer Formation \\
\hline $5 \times 10^{5}$ & Overnight Incubation & Complete Monolayer, with overgrowth of cells at centre. \\
\hline
\end{tabular}

\section{Working Dilution and Inoculum Size:-}


It was observed that the dilution of $10^{-2}$ at the inoculum size of $0.2 \mathrm{ml}$ was suitable for the assay (Table-2). Therefore this dilution and inoculum size were used in the entire study.

At $10^{-1}$ dilution with $0.2 \mathrm{ml}$ of inoculum, plaque formation occurs but due to their large number, their boundaries were seen overlapping and hence plaques were difficult to count. With higher inoculum sizes $0.3 \mathrm{ml}$ and $0.4 \mathrm{ml}$, the plaques were absent due to excessive degeneration of cells.

At $10^{-3}$ dilution, very less number of plaques was obtained. Even with highest inoculum size of $0.4 \mathrm{ml}$, the plaque ranged from 10-20, hence was not suitable for the study. With $10^{-2}$ dilution of the virus, the inoculum size of $0.2 \mathrm{ml}$ produced a uniform distribution of plaques (Table-3). With higher inoculum sizes $0.3 \mathrm{ml}$ and $0.4 \mathrm{ml}$, the plaques formation occurred yet counting could not be made due to excessive degeneration of cells. So, the inoculum size of $0.2 \mathrm{ml}$ was selected as it gave a discrete plaque distribution with round appearance, sharp boundaries and clear margins.

Table 2:- Effect of Different Dilution on the Formation of Plaques.

\begin{tabular}{|c|c|}
\hline Virus Dilution & Results \\
\hline $10^{-1}$ & Very high no. of plaques. Boundaries overlapping. Unable to count. \\
\hline $1-^{2}$ & Plaques were seen as uniformly distributed, discrete, with round shape. \\
\hline $10^{-3}$ & Plaque no. very less. \\
\hline Cell control & Healthy. \\
\hline
\end{tabular}

Table 3:- Effect of Different Inoculums on the Formation of Plaques.

\begin{tabular}{|c|c|}
\hline Inoculum size $\left(10^{-2}\right.$ dilution $)$ & Results \\
\hline $0.2 \mathrm{ml}$ & Discrete plaques were observed. \\
\hline $0.3 \mathrm{ml}$ & No. of plaques was high, unable to count. \\
\hline $0.4 \mathrm{ml}$ & No plaques were seen, rounding of cells and detachment. \\
\hline
\end{tabular}

Image 1: - Shows $10^{-1}$ dilution with $0.2 \mathrm{ml}$ of inoculum. The plaque formation occurs but due to their large number, their boundaries were seen overlapping and hence plaques were difficult to count.

\section{Adsorption time:-}

Maximum plaques were obtained after an adsorption time of 4 hours at $36^{\circ} \mathrm{C} \pm 1^{\circ} \mathrm{C}$. (Table-4) At adsorption time 1 hour there was no plaque development. Therefore the adsorption time of $4 \mathrm{hrs}$ was selected.

Table 4:- Effect of Different Adsorption Times on Plaque Formation.

\begin{tabular}{|c|c|}
\hline Adsorption Time & Results \\
\hline 1 hour & No Plaque development. \\
\hline 4 hours & Good plaques development; maximum no. of plaques seen. \\
\hline
\end{tabular}




\section{Image 2:-}

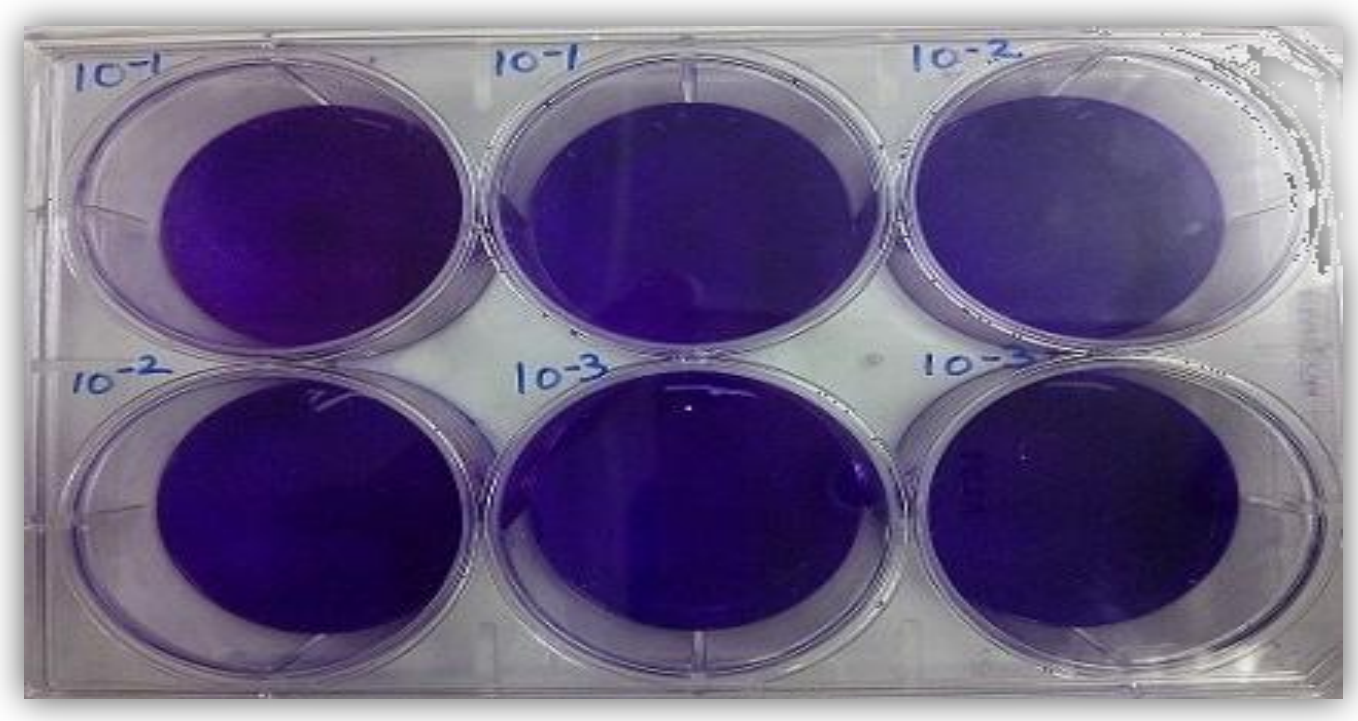

Image 3:-

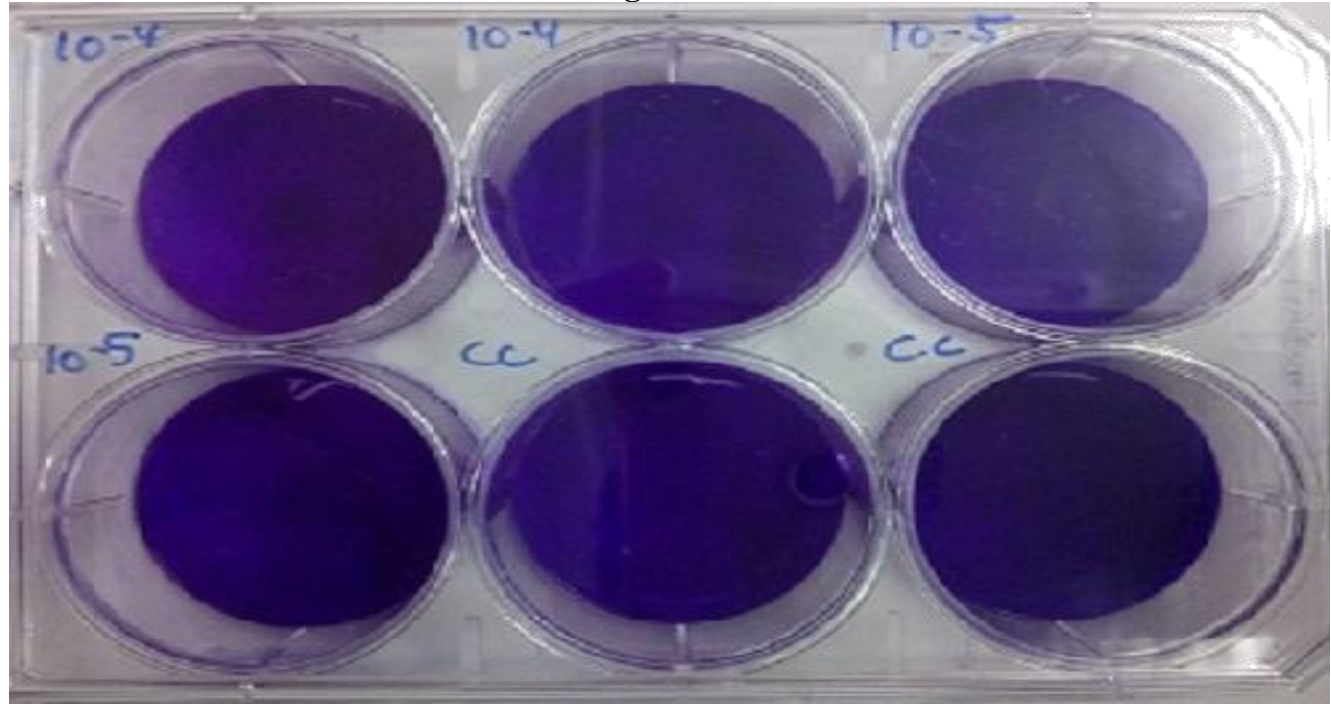

Image-2 and 3:- No plaque development due to incomplete adsorption time period of $1 \mathrm{hr}$.

\section{Methyl cellulose Concentration:-}

It was observed that maximum final concentration of $1 \%$ of Methyl cellulose (MC) in medium (MEM with 2\% FBS) suited well for Vero cells as well as for the formation of plaques. (Table-5)

Low concentration of MC $(0.8 \%)$ could not prevent the spreading of the virus on entire plate. The plaques were seen with diffused boundaries and were not countable.

Table 5:- Effect of Different Concentration of MC on Vero Cells and Plaque Formation.

\begin{tabular}{|l|l|l|}
\hline \multirow{2}{*}{ MC Concentration } & \multicolumn{2}{|c|}{ Results } \\
\cline { 2 - 3 } & \multicolumn{1}{|c|}{ Test } & \multicolumn{1}{c|}{ Control } \\
\hline $0.8 \%$ & Plaques were seen but were not countable & Cells were normal. \\
\hline $1 \%$ & Plaque formation occurred. & Cells were normal. \\
\hline
\end{tabular}



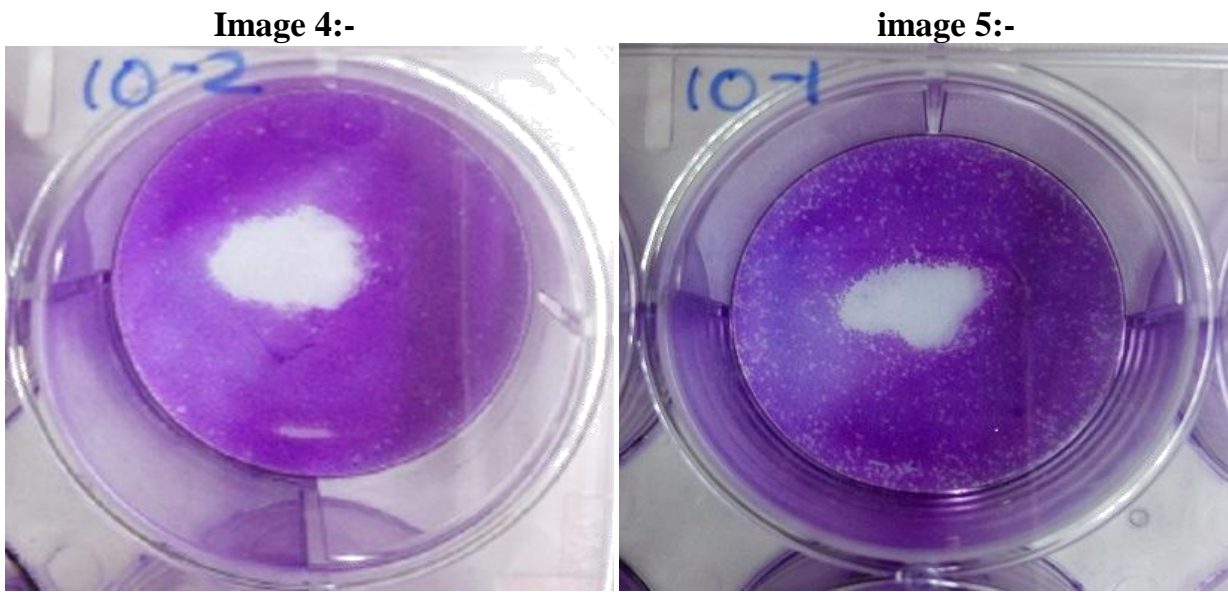

Image 4 and 5:- represents the appearance of plaques of Yellow fever virus in a 6-well tissue culture plates. The first well is inoculated with $10^{-1}$ dilution of the virus and clear but non countable plaques were seen. The 2 nd well was inoculated with $10^{-2}$ dilution and $0.2 \mathrm{ml}$ of inoculum after an adsorption time of 4 hours followed by 7 days of incubation at $36^{\circ} \mathrm{C} \pm 1^{\circ} \mathrm{C}$, and clear countable plaques were seen.

\section{Incubation Time Period:-}

Results of standardization of incubation time showed that plaque development occurred best after 7 days of incubation. (Table-6)

On $5^{\text {th }}$ day of incubation the plaque development was poor as very small sized plaques_were seen. On $7^{\text {th }}$ day clear and distinct plaques were observed.

Table 6:- Effect of Time Period of Incubation on Plaque Development.

\begin{tabular}{|c|c|}
\hline Incubation period & Results \\
\hline 5 days & Small sized plaques; poor development. \\
\hline 7 days & Clear distinct plaques. \\
\hline
\end{tabular}

After standardization of the different parameters for the establishment of the plaques assay on Vero cells, a standardized procedure was followed for the demonstration of the plaques assay. The final results were recorded and photographed. Image1 represents the appearance of plaques of Yellow fever virus in a 6-well tissue culture plates. The first well is inoculated with $10^{-1}$ dilution of the virus and no clear plaques were seen. The $2^{\text {nd }}$ well was inoculated with $10^{-2}$ dilution and $0.2 \mathrm{ml}$ of inoculum after an adsorption time of 4 hours followed by 7 days of incubation at $36^{\circ} \mathrm{C} \pm 1^{\circ} \mathrm{C}$, and clear countable plaques were seen.

Vaccine titration: The final results recorded after standardization of different parameters of Plaque assay method.

Table 7:-Vaccine titre values obtained by PFU Method.

\begin{tabular}{|c|c|}
\hline S. No. & Titre values of test performed (Log10PFU/0.5ML) \\
\hline 1. & 4.50 \\
2. & 4.49 \\
3. & 4.40 \\
4. & 4.47 \\
5. & 4.46 \\
6. & 4.43 \\
\hline MEAN & 4.45 \\
\hline S.D. & 0.37 \\
\hline
\end{tabular}

Test titre values obtained by PFU method are given in Table-7. The lowest and the highest titres were 4.40 log PFU/ $0.5 \mathrm{ml}$ and $4.50 \log$ PFU/ $0.5 \mathrm{ml}$, respectively with mean of 4.45; standard deviation (SD) of 0.037 . The titres obtained from PFU method were all above the minimum requirement for Yellow fever vaccine potency i.e., 4.24 log PFU/ $0.5 \mathrm{ml}$. 
Table 8:-Vaccine titre along with IS titre obtained by PFU Method

\begin{tabular}{|c|c|c|c|}
\hline S. No. & \multicolumn{2}{|c|}{$\begin{array}{c}\text { Titre values of test performed } \\
\text { (Log10 PFU/ 0.5ml) }\end{array}$} & $\begin{array}{c}\text { Titre values of IS } \\
\text { (Log10 PFU/ 0.5ml) }\end{array}$ \\
\hline Batch & A & B & 4.72 \\
1. & 4.50 & 4.47 & 4.67 \\
3. & 4.49 & 4.46 & 4.69 \\
\hline
\end{tabular}

Test was performed with two different batches of vaccine, A and B respectively, along with the test of IRS with PFU method. One sample from each batch was simultaneously titrated with IRS sample. The results obtained are given in Table-8.

Table 9:-Vaccine titre and Manufacturer's titre values.

\begin{tabular}{|c|c|c|}
\hline S. No. & $\begin{array}{l}\text { Titre values of test performed } \\
(\text { Log10 PFU/ 0.5ml) }\end{array}$ & $\begin{array}{l}\text { Titre values of manufacturer } \\
(\log 10 \mathrm{PFU} / 0.5 \mathrm{ml})\end{array}$ \\
\hline 1. & 4.50 & 4.66 \\
\hline 2. & 4.49 & 4.63 \\
\hline 3. & 4.40 & 4.62 \\
\hline 4. & 4.47 & 4.54 \\
\hline 5. & 4.46 & 4.57 \\
\hline 6. & 4.43 & 4.56 \\
\hline & 4.45 & 4.59 \\
\hline S.D. & 0.037 & 0.046 \\
\hline CORR. & \multicolumn{2}{|c|}{0.916} \\
\hline
\end{tabular}

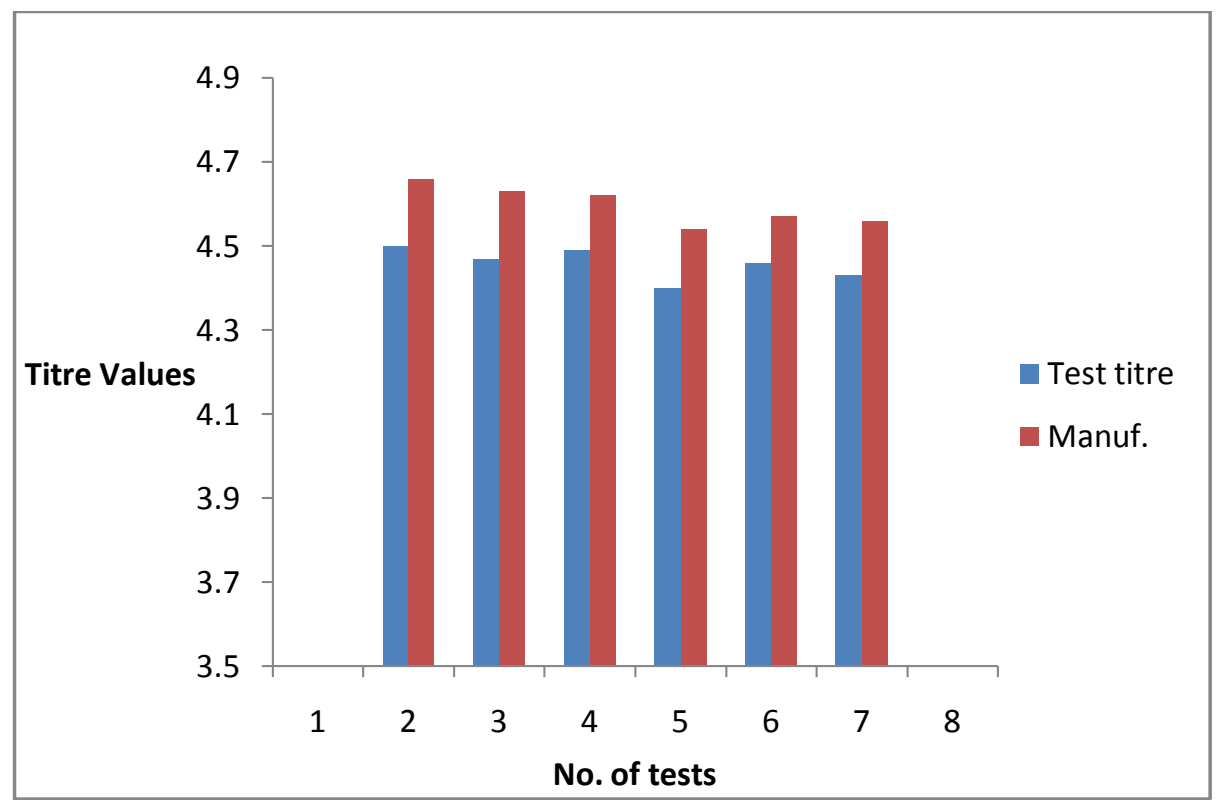

Graph 1:- The different results of titration of two batches A and B compared with the titre values of manufacturer.

6 different vials of Yellow fever 17D vaccine of two different batch numbers (A and B), were titrated for potency testing and were compared with the titre values of manufacturer. The results obtained are given in Table-9 and GRAPH-1. The lowest and the highest titres were $4.40 \mathrm{log}$ PFU/ $0.5 \mathrm{ml}$ and $4.50 \mathrm{logs} \mathrm{PFU} / 0.5 \mathrm{ml}$, respectively with mean of 4.45; standard deviation (SD) of 0.037; and correlation coefficient (CORR.) was 0.91. The titres obtained from PFU method were all above the minimum requirement of Yellow fever vaccine potency i.e., 4.24 log PFU/ $0.5 \mathrm{ml}$. The assay was found to be reproducible. 


\section{Discussion:-}

Vaccine potency of Yellow fever is routinely assay by Mouse $\mathrm{LD}_{50}$ method (in-vivo method). Modern techniques in virology have shown that cell culture techniques are useful for potency and stability tests of many viral vaccines ${ }^{[14]}$. The potency test carried out in mice can be replaced by an alternative cell culture technique (in-vitro) for Yellow fever vaccine ${ }^{[13]}$.

However, Mouse $\mathrm{LD}_{50}$ method is sensitive with a long observation period i.e., 21 days and involves large number of animals ( 8 for each dilution). On the other hand plaque technique is quite sensitive, accurate, less time consuming method for titration. The PFU method gives result in 7 days, and has no use of animals. Many problems of taking care of mice, their food, and breeding etc., and problems faced due to premature death, variation in animal immune status, sensitivity to particular immunological products and variability in results can be avoided.

Keeping in mind the guidelines of RRR, for use of laboratory animals, an attempt has been made through this study to establish Plaque Assay method by replacing MouseLD ${ }_{50}$ method for potency testing, in CRI, Kasauli. As in-vitro Plaque Assay is already established as equivalent method to in vivo MouseLD $\mathrm{L}_{50}$ method, by WHO and also recommended in $\mathrm{IP}^{[11][12]}$.

The manufacturers of Yellow fever vaccine across the world are presently using PFU method to establish the titre of Yellow fever vaccine. In India, the titration of Yellow fever vaccine is being done by using mouse $\mathrm{LD}_{50}$ or $\mathrm{CCID}_{50}$ method. So to harmonize the methodology (as per the ICH guidelines) an attempt to adapt PFU method is made.

Different parameters were standardized for the plaque assay of Yellow fever vaccine on Vero cell line. The plaque assay was carried out in 6-well tissue culture plate. The first parameter was to standardize the cell count of Vero cells to be used per well of the 6-well tissue culture plate. The cell count which gave a complete monolayer formation after overnight incubation was the criteria for the selection. For that, varying number of cells, ranging from $2 \times 10^{5}$ to $5 \times 10^{5}$ per $\mathrm{ml}$, were added to the individual wells of the 6 -well tissue culture plate. The plate was incubated at $36^{\circ} \mathrm{C} \pm 1{ }^{\circ} \mathrm{C}$ for overnight.

The cell count of approximately $3-4 \times 10^{5}$ cells $/ \mathrm{ml}$ were found suitable as the cell number lower than this could not give a complete monolayer formation while on the other hand the cell count higher than $3-4 \times 10^{5}$ cells $/ \mathrm{ml}$, produced a confluent monolayer after overnight incubation, and produced a thick cell sheet and more than $50 \%$ of the cells were found rounded.

Standardization of different parameters for establishment of plaque assay was the next step of the study, such as dilution of the virus inoculum, size of inoculum, concentration of methyl cellulose and incubation time etc.

The dilution of the virus which could give at least $4.24 \log _{10} \mathrm{pfu} / 0.5 \mathrm{ml}$ was also standardized. The dilutions from $10^{-1}$ to $10^{-5}$ were tested and finally $10^{-2}$ dilution was selected, as it gave the desired $\mathrm{pfu} / \mathrm{ml}$.

In case of $10^{-1}$ there is high $\mathrm{pfu} / \mathrm{ml}$ and the entire sheet was found detached due to excessive infection as shown in Image 1 . At $10^{-3}$ dilution of the virus, very less number of plaques was seen. This may be due to low number of virus particles.

After the standardization of dilution of the virus, inoculum size of the virus was also standardized. For this, three different inoculum sizes were tested; $0.2 \mathrm{ml}, 0.3 \mathrm{ml}$, and $0.4 \mathrm{ml} /$ well. Out of these, inoculum size of $0.2 \mathrm{ml}$ was found to be suitable for the study. With $0.3 \mathrm{ml}$ inoculum no major differences was observed. However, with inoculum size of $0.4 \mathrm{ml}$, no plaques were seen due to excessive degeneration of cell line. So Yellow fever virus suspension adjusted to contain $4.24 \log _{10} \mathrm{pfu} / 0.5 \mathrm{ml}$, and the inoculum size of $0.2 \mathrm{ml} /$ well of a 6 -well tissue culture plate were finally selected for the plaque assay.

The effect of different adsorption time on the attachment and development of plaques was also studied. Two different adsorption times were studied i.e., 1 hour and 4 hours. At 1 hour, no plaque development occurred as shown in Image-2 and 3. Best results were obtained at 4 hours of adsorption time and it was selected for the present study. 
In order to localize the plaques, different concentrations of methyl cellulose were incorporated in the overlay media (MEM with 2\% FBS) i.e.; 0.8\%, 1\%. The final concentration of $1 \%$ was found optimum for the plaque assay, as the Vero cells did not show any abnormal behavior at this concentration. 1\% MC just maintained the semi-solid nature of the overlay media, which is quite necessary for the localization of the plaques. The incubation period for the development of plaques was also standardized, and incubation period of 7 days was found to be adequate.

After standardization of different parameters, the reproducibility of the assay was also tested and was found to be good. The plaques were seen as clear, distinct and uniformly distributed. The titration of Yellow fever vaccine was performed on 6 different vials of two different batches along with the IRS and compared with the titre values of manufacturer potency assay. The results show titre above lower limit of $4.24 \mathrm{log}$ PFU/0.5ml. The range of titre results was from 4.40 to $4.50 \log$ PFU/0.5ml with mean of 4.45 ; SD of 0.037 ; and Corr. of 0.91 .

\section{Conclusion:-}

The conclusions of the present study are:-

The plaque formation of Yellow fever 17D vaccine virus is affected by the inoculum size, dilution of virus, duration of adsorption, temperature and concentration of overlay media (MC).

From present study it can be concluded that plaque assay using Vero cell line can be used for potency testing. Mouse $\mathrm{LD}_{50}$ method is sensitive with a long observation period i.e., 21 days and involves large number of animals (8 for each dilution). On the other hand plaque technique is quite sensitive, accurate and less time consuming method for titration.

It is also concluded that PFU method as potency assay of Yellow fever vaccine is reproducible with a mean titre of 4.45; SD of 0.037; and Corr. Coff. was 0.91. However, further studies are required for the establishment of plaque assay method for the potency testing of Yellow fever vaccine.

\section{References:-}

1. Kummerer B.M., Kalitzky M., Borowski P. (2006): The Molecular Biology of Yellow fever virus, In: Molecular biology of the Flavivirus. Norfolk, UK, Cromwell Press-. Pg. 1-16.

2. Gardner C.L., Ryman K.D. (2010): Yellow fever; A remerging threat. Clinical Lab. Med; 30; Pg.237-260.

3. Monath T.P. (2001): Yellow fever an update. Lancet, Infectious disease; 1; Pg. 11-20.

4. Theiler, M. (1951): The Viruses; Yellow fever Virus. Edited by Strode, GK McGraw-Hill Book Company, INC, New York: Pg. 46-136.

5. Ambrosch F., Fritzell B., Gregor J., Jonas S., Kol. H., Teulieres L., Wiedermann G., (1994): Combined vaccination against Yellow fever and typhoid fever: a comparative trial. Vaccines 12 (7): 625-628.

6. Mayo Clinic, (2014): Mayo Clinic Health Systems; Basics of Yellow fever prevention.

7. Monath T.P., Lee C.K., Julander, Brown A., Beasely. (2010): Inactivated Yellow fever 17-D vaccine; development and nonclinical safety, immunogenicity and protective activity. Vaccines; 14; (28); Pg.3827-3840.

8. Robertson S.E. (1993): Yellow fever- The immunological basis for immunization; WHO, Geneva.

9. Barrett A.D., Teuwen D.E. (2009): Yellow fever vaccine - How does it work and why do rare cases of serious adverse events take place? Curr. Opin. Immunologicals, 21; Pg.308-313.

10. Manual of laboratory methods,WHO. (1997): (a);Potency Assay of Live viral Vaccines; Yellow fever vaccine. Pg. 1-3.

11. WHO, (2008): Expert Committee on Biological Standardization, WHO, Geneva, 2008. Requirements for Yellow fever vaccine (Requirements for Biological Substances); WHO-TRS 872.

12. IP- 2014: Yellow fever vaccine (Live). Pg. 2458-2461.

13. Manual of laboratory methods, WHO. (1997): Potency Assay of Live viral Vaccines; Yellow fever vaccine. Pg. 93-97.

14. Caruana J.F., Poirier B., Garnier F., Fuchs F. (2000): In-vitro potency assay of Yellow fever vaccines: Comparison of three Vero cell lines sources. Biologicals; 28(1); Pg. 33-40. 